POLISH POLITICAL SCIENCE

VOL XXXVII 2008

PL ISSN 0208-7375

\title{
"SPILLOVER" IN ACTION - NEOFUNCTIONALISM REVISITED. FREEDOM TO PROVIDE SERVICES OUTSIDE THE COUNTRY OF ESTABLISHMENT AND ITS CONSEQUENCES
}

\author{
by Rafał Riedel
}

\begin{abstract}
Services sum up to $70 \%$ of EU's GDP, and just $20 \%$ of cross-border trade of the European Union - partly due to the unjustified regulatory and administrative burdens implied on different levels of member states administration. The existence of those barriers has stimulated the works on the directive freeing the service sector and implementing a number of rules that may potentially become milestones of integration, compared only to such "history making" moments as Single European Act or Maastricht Treaty.

'The freedom to provide service outside the country of establishment' principle, previously known as the 'country of origin' rule, carries this revolutionary impetus. It will allow a service provider be settled in one EU member state and deliver a service (personally or by delegated employees) in another one with all the legal consequences, especially: some aspects of taxation and social security contributions. Unsurprisingly, it has become one of the most controversial legal acts debated in the last decades Europe-wide. This principle may, to a large extend, undermine the foundations of welfare state, especially in the Western part of continental Europe, as it may force the regulated capitalism oriented countries (like Scandinavian ones) to verify their social policies accordingly to competition pressure coming from lower social standards member states. This may, as it is speculated in this paper, fuel the harmonising of social policies on Community level.
\end{abstract}


Free movement of services was introduced fifty years ago, however it has been usually interpreted from the consumers' perspective: free access to the service by service consumer relocation or trans-border trading. Service provider relocation was tolerated only when accompanied with establishment in the consumer's country. The Service Directive, following the logic of previous European Court of Justice verdicts, introduces - on the secondary law level - the freedom to be established in another country than the country where the service is provided.

This practical challenge is examined theoretically on the grounds of neofuncionalist rationale, as the discussed directive, by its supporters called: the greatest improvement of the internal market since its creation, can act as an empirical proof of neofunctionalism theory applicability. Implementing this approach, especially the revitalised spillover mechanism, is an efficient theoretical vehicle showing satisfactory exploratory power, as well as allowing speculations about the future development on the edge of politics and economy within European integration process. It also highlights the behaviour of supranational actors creating 'stress among the states' to progress the integration into the desirable direction (cultivated spillover).

The deliberations in this paper are rooted in exemplifications of so far practices infringing the free movement of services rule, as well as enriched with some argumentation for and against this form of directive (transformative decisions and legitimacy / democracy deficit).

The arguments used are deeply rooted in final version text of the directive accompanied by interpretation of major principles.

In the conclusive part author summarises that theoretical legacy of neofunctionalism - in the case of the Service Directive - seems to be adequate and the deductive argumentation based on it positively verifies the potential of the theory.

Key words: free movement of services, Bolkestein's directive, neofunctionalism, spillover

\section{CONTEXTUAL INTRODUCTION}

The Service Directive ${ }^{1}$ has been one of the most controversial legal acts, discussed in Brussels and - even more importantly - in member states' capitals. No single piece of secondary law entertained such intense debate comparable only to treaties disputes - "history making" moments of European integration.

1 Directive 2006/123/EC of the European Parliament and of the Council of 12 December 2006, on services in the internal market, "Official Journal” L 376 , 27/12/2006 P. 0036 0068 . 
In public discourse the directive has a "Polish plumber face". Especially in French media, Polish plumber became the stereotypical thinking icon - a symbol of service provider from low standard social security system, that can be competitive, but at the same time endangers the welfare state - "the major achievement of XX century" put in leftist nomenclature.

The European Union developed distinctively in a number of spheres, however social policy remained in the domain of the states' governments, allowing the supranational authority perform only a narrow regulative function resulting in soft harmonization in this area.

The EU Commission seems to be "knocking at the back door" and tries to weaken this (and others) monopoly of the state indirectly. Therefore the Bolkestein's directive (named after its "father": Frits Bolkestein - Dutch by nationality and liberal by ideology) being the greatest improvement of the internal market since its creation can act as an empirical proof of neofunctionalism theory applicability.

Neofunctionalism is still alive, revealing - among others - in liberalization tendency in service market, which deepens integration and creates pressure on related spheres as well as in actions undertaken by Community actors, namely the EU Commission (EUC) and European Court of Justice (ECJ).

It is not surprising that the most controversial part of the Bolkestein's Directive was the country of origin principle. Being the core of the act, this principle would allow the service provider to be settled in country A (and consequently pay taxes, social system contributions, etc. accordingly to the country A system), and provide service in country B. At the same time take the competitive advantage from the cost disparities of particular welfare systems. (Riedel, 2007) ${ }^{2}$

Implementing this principle lets us predict that the free market of service will have its important impact on harmonizing - and hypothetically, in result, maybe even integrating - social policies. Consequently we may talk here about the "spillover" effect. The mechanism, which - according to neofunctionalists' theory - will create an impulse for integrating in neighboring (corresponding) spheres. (Lindberg, Scheingold, 1970). Revolutionary nature of the potential impact of Service Directive on related spheres reveals, when one realizes that the corresponding area (social policy solutions) has been so far effectively shielded by the state.

2 R. Riedel, Bolkenstein's Directive on Services - Quo Vadis Europe?, [in:] "Globalization and Policies of Development" Proceedings of the Globalization and Policies of Development, International Conference, 17-19.05.2007, Bucharest, Romania, Organizer: National School of Political Studies and Public Administration, Paul Dobrescu, Andrei Taranu and Alina Bargaoanu (eds.) by, pp. 349-358. 
The country of origin principle has not become controversial just in the case of the Service Directive but also other secondary law acts. For example, it appeared also in E-commerce Directive ${ }^{3}$ causing great confusion. E-service providers claimed and advocated that its provision should be understood as a choice of law rule designating the law of the place of establishment of the service provider as applicable (Hellner, $2004 ; 193){ }^{4}$

\section{THEORETICAL BACKGROUND}

As we know, due to their exploratory power, functionalist approaches have been essential to the study of international integration, especially in the beginning phase of the real-life integration process ${ }^{5}$. Later on, some other strands of integration theories gained popularity, including transactionalism, new institutionalism, realism and liberal intergovernmentalism, (deliberative) suprnanationalism, multilevel governance, and also frequently revisited federalism. This discourse is still vital, reflecting the current developments on the "Old Continent". Apart from the above mentioned, theoretical debate is also rich with contemporary, on-line deliberations on EU governance, its legitimacy, accountability, representation and democratic deficit - opening the door for the theories outside the traditional "international relations" discipline, which served for decades providing scholars with models, terminology and observation matrix. Fellows researching the political and economic process of European integration explore also traditional political science theories of state, democracy and others, enriching the so far theorizing in a way that responds to the integration process dynamics, especially in post-Maastricht era.

At the same time we should be constantly theoretically self-aware. As it was put by Ben Rosamond: conscious that theoretical perspectives - wittingly or unwittingly - inform our approach to the world we observe. ${ }^{6}$

So far many scholars have tended to apply neofunctionalist matrix to integration processes mainly from the political and economic perspective, less frequently from the legal point of view. ${ }^{7}$ This paper tries to combine legal and political as well as

3 Directive 2000/31/EC, OJ L 178, 17 July 2000, pp 1-16

$4 \mathrm{M}$. Hellner, The Country of Origin Principle in the E-commerce Directive - A conflict with Conflicts of Laws?, „European Review of Private Law”, 2004, No. 2, p. 193.

${ }^{5}$ For many integration theory and neofunctionalism are still synonymous.

${ }^{6}$ B. Rosamond, The Uniting of Europe and the Foundation of EU Studies: Revisiting the Neofunctionalism of Ernst B. Haas, „Journal of European Public Policy” 2005, No. 12.

7 G. de Burca, Rethinking Law in Nefunctionalist Theory, "Journal of European Public Policy" 2005, No. 12. 
economic dimension of liberalizing service market into a multi-level analysis, as such perspective - in the author's opinion - sufficiently addresses the nature of the Bolkestein's directive.

David Mitrany's - the father and classic representative of functionalist theory mantra: the form follows the function should act as a good starting point. However - as neofunctionalist ideas emerged most clearly in the works of Ernst Haas - the emphasis on actors and their interaction seems to be more adequate. What we owe to neofunctionalists is not only their logic of thinking and vocabulary for the analysis but also strong emphasis on integration in terms of process rather than outcomes.

The key question of neofunctionalism is whether (and how) economic integration can lead towards political one. In the case of Bolkestein's directive the correlations between the economic and political domains are far too complex to be covered in a paper scale, therefore it is just necessary to conclude in a synthesized form that it illustrates a situation in which political integration "finalizes" the economic one. Which is constant interaction process as it is rational to predict that the "finalized" economic integration is going to create new "pressures" on political dimension - as it is argued in this paper: social policies.

When building theoretical background, rooted in neofunctionalist strand, for service market dynamics (under the new directive), it is predominantly necessary to focus on the mechanism of spillover.

Spillover refers to the way in which the creation and deepening of integration in one economic sector would create pressure for further economic integration within and beyond that sector, and greater authoritative capacity at the European level.

As it is formulated by one of the neofunctionalists - Philippe Schmitter: "Spillover (...) refers to the process whereby members of an integration scheme - agreed on some collective goals for a variety of motives but unequally satisfied with their attainment of these goals - attempt to resolve their dissatisfaction by resorting to collaboration in another, related sector (expanding the scope of mutual commitment) or by intensifying their commitment to the original sector (increasing the level of mutual commitment), or both. ${ }^{8}$

This core statement reveals also another important argument of neofunctionalists stating that states are not the only important actors on the international scene.

8 P. Schmitter, Three Neofunctional Hypotheses about International Integration, „International Organization" 1969, No. 1, vol. 23, p. 162. 
As a consequence, neofunctionalists focus their attention on the role of supranational institutions and non-state actors, such as interest groups and political parties. ${ }^{9}$

The integration of particular economy sectors across nation states will create functional pressures for the integration of related economic sectors. This momentum is likely to continue, especially with the guiding role played by the impresario high authority. The consequence is the gradual and progressive entangling of national economies. ${ }^{10}$

It was another neofunctionalist - Leon Lindberg, who explored the idea that progress in integration could actually deter further integration. Integration could be "a source of stress among states" as encroachments upon governments, resulting in a sort of snow-ball effect. ${ }^{11}$ This conceptualization seems to be predominantly important in the case of 'freedom to provide services outside of the country of establishment' principle, which is an element of the Service Directive. It describes the mechanism in which free movement of services may impact social security standards in the member states of the union, which is going to be proved in the empirical part.

Final theoretical contribution that should be employed in this paper is the concept of cultivated spillover, which refers to the situation in which supranational institutions act as strategic advocates on behalf of functional linkage and deeper or / and wider integration ${ }^{12}$. In this case when supranational actors (like EUC or ECJ) try to push forward a supranational or transnational agenda, even where member states are reluctant to accept further integration. ${ }^{13}$

\section{WHY DO WE NEED THIS DIRECTIVE?}

Many of us, academics, for a long time have been teaching European integration courses persuading students on four fundamental freedoms constituted in the 50 . XX c. treaties. One might ask: why do we still need - fifty years after - a directive which delivers freedom guaranteed on a treaty level. The answer - as usual in such cases - is application. Law 'in action' and 'low on paper' differ too much sometimes.

9 C.S. Jensen, Neo-functionalism, [in:] M. Cini, European Union Politics, Oxford University Press, Oxford 2003, p. 81.

10 B. Rosamond, The Uniting of Europe..., op.cit.

11 L.N. Lindberg, Integration as a Source of Stress on the European Community System, "International Organization" 1966, No. 20 (2).

12 B. Rosamond, The Uniting of Europe..., op.cit.

13 C.S. Jensen, Neo-functionalism..., op.cit., p. 85. 
In its report, the EU Commission identified more then 90 types of practices implemented on all levels of member states' administrative structure, creating barriers for free movement of services, among them: difficulties in license issuing, administrative permissions procedures, obligation of settling a permanent unit in the country where the service is going to be provided, as well as other sorts of discriminating foreign individuals or entrepreneurs.

Among the most spectacular examples, Greece is supposed to be the typical one, where for instance the driving school instructors must speak Greek language. Such a requirement seems to be logic until one realizes that just in Athens there is a market niche of more than one hundred thousands non-Greek potential clients, who would not necessarily like to be taught in Greek.

The major problem appears, when we see the barriers in free movement of service in the prism of social standards protectionism. Some EU member states (those with rich welfare systems) become endangered with the competition pressure from lower social standards systems. This danger does not turn to be effective when free movement of product, people or capital is concerned. In these cases the welfare systems do not compete as the foreign employee, as well as the company that decides to invest in another member state, must pay taxes and social contributions to the budget where he/she/it functions.

Whereas, only free movement of service creates a possibility of being registered in one country (meaning - be rooted in one welfare system) and operate in another one.

Consequently, some EU member states practiced different kinds of barriers aiming at protection of local service providers from foreign competition (from systems less ballasted with the weight of comfortable and expensive welfare solutions).

In general, the Bolkestein's intention was to eliminate such and this type artificial barriers that should not be administered and decided by local authorities but free market principles, with the guarantee of Community law.

As implementing such protectionism practices brings about cumulated effect in lower level of competitiveness, less spectrum of choice, poorer quality and higher prices. ${ }^{14}$

The prerequisites for the Directive, presented in this paper stay in accordance with the Commissions report on "The State of the Internal Market for Services" which identified a large number of barriers which are preventing or slowing down the development of services between Member States, in particular those provided by

${ }^{14}$ H. Kox, A. Lejour, R. Montizaan, The Free Movement of Services within the EU, CPB Document no. 69, The Hague, October 2004; M. Fuchs, Free Movement of Services and Social Security - Quo Vadis?, "European Law Journal" 2002, No. 4 vol. 8. 
SMEs, which are predominant in the field of services. The report concludes that a decade after the envisaged completion of the internal market, there is still a huge gap between the vision of an integrated European Union economy and the reality as experienced by European citizens and providers. ${ }^{15}$

Free movement of service may be carried on in four basic forms: trans-border trading, consuming the service in another country, the presence of service provider in another country or relocating the service provider's labor force, employees (for example: construction services). ${ }^{16}$

Trans-border character - accordingly, the free movement of services regulations must be implemented in a situation when:

a) Service provider (self-employed enterpreneur, free profession holder) relocates to his consumer to another member state - an individual with EU citizenship, companies with headquarters in one of the member states.

b) Service consumer relocates to service provider to another member state - usually tourists or medical treatment (not publicly financed) consumers.

c) The service itself crosses its borders, and the service provider and consumer do not relocate, for example TV or radio broadcasting.

It is important to point here, that the degree of liberalization of services traffic is not the same in every service group. Generally those service sectors that do not involve relocation of service provider - for example, internet banking or telecommunication - have been under competition pressure of the Single Market for a long time. And in such cases the Bolkenstein's Directive does not change much.

The situation is completely different when we have in mind free movement of service providers. Free movement of people allows them to relocate as employees, free movement of capital allows them to establish a company outside the country of their origin, free movement of products allows to sell the service, but when treated as a product - meaning that the service crosses the border (not the provider). And the free movement of service that should allow the firm or individual- registered in one member state - to provide services in another one, has not been functioning so far. Due to numerous, mainly administrative obstacles (generated by local or state authorities) the service providers could not effectively compete in the scale of the Community.

15 Directive 2006/123/EC of the European Parliament and of the Council of 12 December 2006, on services in the internal market, “Official Journal” L 376 , 27/12/2006 P. 0036 0068 .

${ }^{16}$ J. Pietras, Swoboda świadczenia usług [in:] Unia Europejska, (ed.) E. Kawecka-Warzykowska, E. Synowiec, Warszawa 2004, p. 96. 
Nevertheless, the vital importance - when identifying the reasons of delay in freeing the service market - should be recognized outside of the euro-bureaucratic domain. Much more decisive were such questions, like the fact that services usually are delivered by self-employed (craftsmen, free professions, etc.) and are heavily regulated by country-level law - for example doctors or attorneys.

Special emphasis must be given to the context of the directive in public services, which are not under competition pressure even in the scale of the state. This constitutes its most important political dimension.

Certainly, not every type of service must be market regulated. For example health service in any developed country is left exclusively to free market mechanism. And the state heavily influences it by regulatory or redistrbutive function.

Therefore one can expect that, wherever we deal with public service or public private partnership, the liberalization process will develop slower, if ever. Some sectors of public service will never be open for free market competition.

However, one of the possible scenarios is that Europe will work out a system of answering the social needs - still in the public sphere - on the Communities level. This would require breaking the monopoly of the state and arming the Union with input type legitimacy.

Also the European Court of Justice - in its verdicts - underlines that the Community has no competences in organizing public social service. Misunderstandings connected with free movement of service have been very often connected with obligatory social insurances, obligatory chambers, unions, etc.

On the other hand, the presence of social policy elements on the Community level from the very beginning (Paris and Rome Treaties) reveals the intentions of "fathers of integration" who foresaw harmonization of social protection systems. Moreover, some authors - for example Maxymilian Fuchs claim that from the very beginning it was one of the conditions of creating Single Market. ${ }^{17}$

The rationale of such thinking is hidden in the final version of the directive, which - due to the spillover mechanism - will affect, in a long turn, welfare systems creating functional pressure on member states to harmonize its important elements. Otherwise, due to developing transport and telecommunication, IT technologies and other 'inventions' of globalization, the member states will not be able to avoid rivalry among the welfare systems - searching and delivering more and more competitive conditions for investors in a market sector, who will choose the place of their establishment on the criterion of low tax and security system contributions.

Those who criticize this function of the directive need to take into account that it is the Communities understanding of the four free movement of service principle.

17 M. Fuchs, Free Movement of Services..., op.cit. 
It is interesting to follow some of the ECJ judgments ${ }^{18}$, where it - in a case law manner - reveals very wide interpretation and vision of free movement of services $^{19}$ :

- Free movement of service should be understood both in its passive as well as active variant: accordingly it consists both of free access to the service as well as freedom in providing the service.

- Consequently, free service market comprises of possibility of (cross-border) relocating service consumer as well as temporary (cross-border) relocating of service provider.

- Country of origin of the service provider or consumer may not act as an argument in discrimination practices. ${ }^{20}$

Worth mentioning, also article 51 of Rome Treaty, states that co-ordination of policies in the sphere of social protection systems should guarantee other freedoms.

However so far, the resistance from the member states' governments appeared to be effective enough. Even in situation (before the 2004 enlargement) when the communities consisted of relatively well developed countries, with GDP per capita PPS (Purchasing Power Standard) not so huge disparities. It seems therefore little probable that, after inviting Central and Eastern European countries that differ much from the EU 15 both in GDP level as well as in welfare standards, the harmonization of social security systems would happen on Community level.

When the directive is implemented, together with its country of origin principle ${ }^{21}$, and at the same time no steps are undertaken in the field of harmonization of welfare

${ }^{18}$ However the final version of the directive covers a number of exceptions identified: "According to the case law of the Court of Justice, public health, consumer protection, animal health and the protection of the urban environment constitute overriding reasons relating to the public interest. Such overriding reasons may justify the application of authorisation schemes and other restrictions". (Directive 2006/123/EC of the European Parliament and of the Council of 12 December 2006, on services in the internal market, Official Journal L 376, 27/12/2006 P. 0036 - 0068; 43).

19 Resulting in exactly the same consequences - however in a case low procedure.

${ }^{20}$ P. Craig, G. de Burca, EU Law. Text, Cases and Materials, 2nd edn, Ofxord University Press, oxford 1998.

${ }^{21}$ In the works of EU Parliament the country of origin principle went through the process of "re-modeling". Nevertheless, its supporters decided to accept it in this form - as a compromise solution - believing in eventual future corrections. Any other solution could mean the collapse of the initiative in total. However it is important to state that the "re-modeling" is just a cosmetic change + for example it changed its name to: freedom to provide service principle. But the major power of this principle and the whole act remained, meaning that 
systems, then we can expect the phenomenon of allocating companies and individuals to countries with lower taxation and social contributions obligations.

Such a trend would mean the "night mare of a socialist", race to the bottom competition among social protection systems (lowering their costs and limiting service - at the same time limiting the territory where the state performs the largest part of its redistributive functions).

Such a danger is perceived and is an important topic of public discourse in Europe, very often CEE countries are accused of practicing so called social dumping.

The above description of a supranational authority creating pressure on member states (logical from neofunctionalist point of view) is also interesting from another perspective: legitimacy of such a phenomenon. As it is argued, by Armin Schaefer and Martin Hoepner, that the EU Commission and ECJ attempt to further integration in the spheres that conventionally were (input) legitimized within nation-state political process. And the service directive demonstrates that both of the UE institutions aim at liberalizing more than the member states ever explicitly asked for in the treaties. Specifically, country of origin principle may result in a situation, in which member states are limited in their capacity to supervise and govern economic actions within their own territory. ${ }^{22}$ It is quite problematic due to the deficit of democracy issue, but also taking into account the variations of capitalism present within the EU (supranational pressure on harmonization vs. national varieties of capitalism). ${ }^{23}$

Social policy, being a very sensitive component of each country's socio-economic model and large part of state governments redistributive authority, has been so far carefully isolated since the communities inception - well shielded from EU policy and polity. In the case of liberalizing the service market - in the form proposed in the directive - it is obvious that we experience a situation in which EU decisions have transformative impact on national economies. Such processes are well described and debated within the Europeanization stream and can be also analyzed through the prism of neofunctionalism, as it is proposed in this paper.

once an individual and a company are registered in one of the member states, they can provide service on the whole territory of the union.

${ }^{22}$ M. Hoepner, A. Schaefer, A New Phase of European Integration. Organized Capitalisms in Post-Ricardian Europe, MPIfG Discussion Paper - 07/4 Cologne 2007, p. 11-13.

${ }^{23}$ Directive caused fierce protests, especially in organized economies (in contradiction to liberal market economies, organized economies feature or non-market coordination between stakeholders or high degree of institutionalization of economic performance or both). Ibidem, p. 6. 
The question: if it is adequate to produce transformative decisions without (input) legitimacy ${ }^{24}$ is of political nature and, at the same time, creates a large arena for academic deliberations.

Applying a wide interpretation of the four freedoms, shown in Commission's determination during the legislative process and EJC's verdicts and its justifications exemplified above, seems to expand liberalization to an extent that intergovernmentalism does not predict, which positively verifies the concept of applying neofunctionalism as a theoretical vehicle for this analysis.

The European Union has - especially in its initial phase - traditionally focused on essentially economic tasks. Its role in such spheres as foreign policy, justice, home affairs, and the welfare state is weak, reflecting the member states' lack of interest in losing control over those policies and consequently those aspects of politics. ${ }^{25}$

\section{REAL LIFE AND POLITICS}

This clash of rationalities - intergovernmental versus neofunctionalist logic of integration - is not only of theoretical nature. The ECJ procedures show that different understandings and interpretations bring serious consequences for individuals, companies, labor unions and other actors.

Good exemplification comes from Swedish city of Vaxhall, where the local authorities intended to build a school. According to European law, in the appropriate legal procedure, the contract was won by a Latvian construction company "Laval". Their offer could be more competitive as they could calculate - among others - lower salaries for the workers. In the middle of the building process, the construction site was blocked by Swedish labor unions protesting against hiring people on economic conditions below the standards negotiated in Swedish collective agreements. The blocking lasted long enough for "Laval" to go bankrupt. Its owners sued the Swedish government for not-providing necessary measures (against the Swedish labor union) enabling the Latvian company to entertain free movement of services principle.

The case is at this moment in the European Court of Justice and the Commission claims the rights of the Latvian company against Swedish government.

This example highlights the urgency of the problem, which is covered in the Service Directive in order to avoid case law proceedings in each and every situation. So far - before the Service Directive was agreed - the ECJ interpretations were as follows:

${ }^{24}$ Can it go so far (social policies) without legitimacy?

25 S.C. Greer, Uninvited Europeanization; neofunctionalism and the EU in health policy, „Journal of European Public Policy” 2006, No. 13, p. 134. 
“(...) Where an operator travels to another Member State to exercise a service activity there, a distinction should be made between situations covered by the freedom of establishment and those covered, due to the temporary nature of the activities concerned, by the free movement of services. As regards the distinction between the freedom of establishment and the free movement of services, according to the case law of the Court of Justice the key element is whether or not the operator is established in the Member State where it provides the service concerned ${ }^{26}$. If the operator is established in the Member State where it provides its services, it should come under the scope of application of the freedom of establishment. If, by contrast, the operator is not established in the Member State where the service is provided, its activities should be covered by the free movement of services". ${ }^{27}$

At the same time, as it can be imagined, such cases have strong political background both locally as well as in the sphere of 'high politics' on national or international level.

Commentaries of French "No" and Dutch "Nei" in referendum on ratification of Treaty Establishing the Constitution for Europe (May/June 2005) say that to a large extent such voting was rooted - among others - in French society's dislike aversion for Bolkenstaine's initiative.

This is of course a pre-requisite in discussion on the optimal form of decision making in Europe - if referendum is an adequate method of international treaties' ratification procedure.

As we know from public opinion surveys reports, both the French, as well as the Dutch, who said "No" one week later, not only did not have much meritorious knowledge on the act as well as they treated this occasion as an opportunity for expressing their euro-frustrations, political affects rooted very often in internal politics. We could observe the same situation in Spain (March 2005), where the voters said "Yes" however they were equally incompetent in this issue as the French and the Dutch - just the general euro-enthusiasm was on higher level there.

Another political context - in 2003-2005 also Germany was one of the more active opponents of the service directive. This has changed at the end of 2005, together

26 The Court of Justice has consistently held that the temporary nature of the activities in question should be determined in the light not only of the duration of the provision of the service, but also of its regularity, periodical nature or continuity. The fact that the activity is temporary should not mean that the provider may not equip itself with some forms of infrastructure in the Member State where the service is provided, such as an office, chambers or consulting rooms, in so far as such infrastructure is necessary for the purposes of providing the service in question. (Directive 2006/123/EC of the European Parliament and of the Council of 12 December 2006, on services in the internal market, Official Journal L 376, 27/12/2006 P. 0036 -0068; p. 46).

27 Ibidem. 
with the change of the government in Berlin. Angela Merkel decided to support the directive - together with United Kingdom, the Netherlands, Poland and other new member states.

It is also important to state that the discussed points of view differ not only accordingly to the economic philosophy (liberal vs. regulated capitalism), but also has its geo-political dimension. From the perspective of Central European countries, like Poland, Hungary, Slovakia or Czech Republic (due to their socio-economic specifics) implementing the directive is beneficial as service providers from these countries - thanks to less costly welfare systems - will gain competitive advantage. Therefore liberalization of free movement of services is strongly supported by the representatives of these countries in every possible form both in EU parliament (by eurodeputies) as well as EU Council (in inter-governmental negotiations).

However not only political particularizm rationalizes this reform. Treating the union as one entity, it is also argued that protectionism (on service market) within the Single Market is counterproductive for the whole block in international economic relations and internal dimension of competitiveness.

And the internal problem of competition between welfare systems should also be solved in the form of coherent social policy harmonization on EU level, rather than short - time perspective ignoring globalization trends. ${ }^{28}$

For example, EU Commission simulates that the directive will generate additionally $1,8 \%$ GDP growth and 2,5 mln now jobs. ${ }^{29}$

Taking into account the present indications of economic growth in the union (EU average) and unemployment problem, the directive has a chance to be a key instrument in realization of many sectoral and horizontal policies, including Lisbon Strategy. The supporters of the directive foresee, that its implementation will fuel economic growth ${ }^{30}$, create new jobs and improve market supply.

A PricewaterhouseCoopers study provides insight into the difficulties faced by law firm looking to expand their services across Europe. The study shows that one

${ }^{28}$ N. Fligstein, J. McNichol, The Institutional Terrain of the European Union, [in:] European Integration and Supranational Governance, W. Sandholtz, A. Stone Sweet (eds.), Oxford University Press, Oxford 2001.

${ }^{29}$ See: Copenhagen Economics, Economic Assessment of the Barriers to the Internal Market for Services - Final Report, Copenhagen 2005.

${ }^{30}$ Ian McCartney (British Minister of State for Trade, Investment and Foreign Affairs) foresees that the directive's input to British economy may be estimated around 5 bln pounds per year. 
international law firm with 165 partners and 600 staff faced real barriers when it tried to expand to two Eucountries outside UK. ${ }^{31}$

The opponents of the directive underline the negative consequences it may bring for social protection standards. For example in France, where "the achievements of the labor are very rich", but at the same time costly and ballasting, which is crucially important in confrontation with service providers from countries having welfare systems. The labor unions predict the advantages and disadvantages of the directive will not be distributed fairly, which argument itself can act as a weak side of the reform.

Eveline Gebhard - a socialist euro-deputy, whose responsibility was to report on the EU Parliament plenary session on the legislative works on the service directive. Still in 2005, Eveline Gebhard proposed resigning from, as much controversial as vital, country of origin principle (enabling an entrepreneur registered in one country to provide service in another member country).

E. Gebhard proposed that the liberalization of services sector should be accomplished according to the bilateral, mutual acknowledgment principle. Meaning, the states' governments would individually negotiate the conditions under which their citizens and entrepreneurships could provide service in a foreign country.

Such an approach would also be a huge step behind the rationality of integration process. Free movement of services once agreed on community level would be rediscussed, re-negotiated and re-decided in international dimension (back to intergovernmental domain). ${ }^{32}$

In March 2006, heads of member states, gathered on a council summit in Brussels, expressed their satisfaction with the "improvements" of service directive, that were implemented in February 2006 - in the first reading in the EU Parliament. The participants of the summit point that the union's service market must correlate with "European social model".33 (). In Euro-crats "novo-mova", it meant the essence of the directive became disarmed and sacrificed.

\section{THE LOGIC OF THE DIRECTIVE}

During the legislative process the text, and consequently content of the Service Directive changed many times accordingly in response to intergovernmental bargain-

${ }^{31}$ I. McCartney, LLPs can flourish under new EU Services Directive, “The Lawer", 21.11. 2006, p. 8.

32 Editorial Comments on the Service Directive Proposal Common Market Law Review 2006, No. 43: pp. 307-311.

33 PAP, 24.03.2006. 
ing in the Council and political arguments in the EU Parliament. ${ }^{34}$ The legislative works on the directive lasted years, finally completed in 2006, when the new Commissioner for Single Market was Charlie McCreevy. Its final version was agreed $12^{\text {th }}$ December 2006 and publicized in Official Journal on $27^{\text {th }}$ December 2006 with the intention to go into force from the beginning of 2010, art. 44 claims that member states should imply provisions necessary to comply with the service directive before 28 December 2009.

The main goal of the Service Directive remain the same as in Frits Bolkestein's intention: creating a single market for free movement of service in the European Union.

The directive responses to Article 14(2) of the Treaty establishing the European Communities, which claims that the internal market comprises of an area without internal frontiers in which the free movement of services is ensured. In accordance with Article 43 of the Treaty the freedom of establishment is ensured.

The handbook on the implementation of the service directive ${ }^{35}$, published by the EU Commission, explains the relation of this act to the EC Treaty:

"Like any piece of secondary legislation, the Services Directive needs to be seen in the context of primary law, i.e. the Treaty establishing the European Community (EC Treaty) and notably the Internal Market freedoms. The Directive must be interpreted and implemented in this context. It should also be clear that matters excluded from the scope of the Services Directive remain fully subject to the EC Treaty. Services excluded remain, of course, covered by the freedom of establishment and the freedom to provide services. National legislation regulating these service activities must be in conformity with Article 43 and 49 of the EC Treaty and the principles that the European Court of Justice (ECJ) has developed on the basis of the application of these articles have to be respected" ${ }^{36}$

The barriers described in this paper cannot be removed solely by relying on direct application of Articles 43 and 49 of the Treaty, since addressing them on a case-bycase basis through infringement procedures against the Member States can not be treated as a standard procedure due to its ineffectiveness.

Therefore the Directive directly claims that the concept of provider should not be limited solely to cross-border service provision within the framework of the free

34 The dynamics of the process may be followed and re-tracked on EU Commissions web pages, archiving historical versions of the text, positions of stakeholders and their argumentation: http://ec.europa.eu/internal_market/services/services-dir/background_en.htm

${ }_{35}$ Handbook on the Implementation of the Service Directive. Commission of the European Communities. Internal Market and Services DG, Brussels 2007

${ }^{36}$ Ibidem, p. 8. 
movement of services but should also cover cases in which a service provider establishes itself in a Member State in order to develop its service activities there. ${ }^{37}$

While Articles 9 to 15 concern the establishment of service providers, Articles 16 to 21 deal with cross-border service provision, i.e. cases where the service provider is not established in the Member State in which he provides services. The distinction between establishment and cross-border service provision is thus fundamental in order to determine under which rules of the Directive a service provider falls.

The core problem of the liberalisation envisaged in the 'country of origin' principles is addressed in chapter 4 ("Free Movement of Services"), section 1 ("Freedom to provide services and related derogations"), article 16, point 1: "Member States shall respect the right of providers to provide services in a Member State other than in which they are established." ${ }^{38}$

So far the distinction between establishment and provision of services was made on a case-by-case basis by the ECJ, taking into account not only the duration but also the regularity, periodicity and continuity of the provision of services. It was concluded by the ECJ, that there can be no general time limits set in order to distinguish between establishment and service provision ${ }^{39}$.

The ECJ explained that even an activity carried out over several years in another Member State can be considered to be service provision within the meaning of Article 49 of the EC Treaty. Consequently the service providers will know that they will not be subject to the legislation of the receiving Member State, as far as taxation and social security contributions are concerned.

This does not mean however, that the service provider working in another (than the country of establishment) member state will be totally out-rooted from the legal system of the host country. He/she will have to follow, for example, the safety and hygiene at work regulations specific for the host country. More importantly, in the situation of workers posted to provide a service in the territory of another Member State, the providers have to comply with terms and conditions of employment in a listed number of areas applicable in the Member State where the service is provided. These are: maximum work periods and minimum rest periods, minimum paid annual holidays, minimum rates of pay, including overtime rates, the conditions of hiring

37 Directive 2006/123/EC of the European Parliament and of the Council of 12 December 2006, on services in the internal market, "Official Journal” L 376, 27/12/2006 P. 0036 0068, p. 40.

38 This principle shall not apply however in the following cases: services of general economic interest which are provided in another Member State, the postal sector, in the electricity sector, the gas sector, water distribution and supply services and waste water services, treatment of waste. (art. 17).

${ }^{39}$ Handbook on the implementation..., pp. 48-49. 
out of workers, in particular the protection of workers hired out by temporary employment undertakings, health, safety and hygiene at work, protective measures with regard to the terms and conditions of employment of pregnant women or women who have recently given birth and of children and young people and equality of treatment between men and women and other provisions on non-discrimination. ${ }^{40}$

As far as other provisions of the directive are concerned, it is also worth mentioning that - as it was easy to predict - the directive includes a list of services that are excluded from the free movement of services, for example: postal services, audiovisual, work agencies, security, public transport, public health care system, etc. ${ }^{41}$

Additionally, the authors of the directive put special emphasis on simplification of procedures and the right to information (guaranteed on the Community level). State authorities that are involved in procedures connected with establishing companies, obtaining permission, issuing licenses, etc. to provide electronic access to these services as well as organize one-stop-shops, where all the formalities can be dealt with.

40 Directive 2006/123/EC of the European Parliament and of the Council of 12 December 2006, on services in the internal market, "Official Journal" L 376 , 27/12/2006 P. 0036 0068, p. 47.

${ }^{41}$ Article 2 consists of a full list of service sectors in which the Directive shall not apply: non-economic services of general interest, financial services, such as banking, credit, insurance and re-insurance, occupational or personal pensions, securities, investment funds, payment and investment advice, electronic communications services and networks, and associated facilities and services, services in the field of transport, including port services, services of temporary work agencies, healthcare services whether or not they are provided via healthcare facilities, and regardless of the ways in which they are organised and financed at national level or whether they are public or private, audiovisual services, including cinematographic services, whatever their mode of production, distribution and transmission, and radio broadcasting, gambling activities which involve wagering a stake with pecuniary value in games of chance, including lotteries, gambling in casinos and betting transactions, social services relating to social housing, childcare and support of families and persons permanently or temporarily in need which are provided by the state, by providers mandated by the state or by charities recognised as such by the state, private security, services provided by notaries and bailiffs, who are appointed by an official act of government. 


\section{CONCLUSIONS}

Despite the fact that already the Rome Treaty (25th March 1957) initiated free movement of products, services, capital and labour, the next fifty years of integration process has not resulted in factual functioning of free market competition and consequently competition pressure in this sector within Single Market.

The original version of the directive - proposed by then Single Market Commissioner - foresaw eliminating all types of barriers, that would allow to provide service by a company or individual based in any member state on the whole territory of the union - gaining name of 'country of origin principle'.

This principle remodelled and renamed still keeps its legal power, especially in relation to self-employed service providers who would intend temporarily or permanently provide service outside the country of their establishment.

The demand for the directive emerged from the fact that contemporarily entrepreneurs face numerous barriers - mainly of administrative nature - when trying to provide service outside the borders of the countries of their origin. This problem is brought about by the necessity of sticking to local regulations, which - usually unjustified - aim at protecting local markets from competition pressure from outside.

When analysing the integration level in service sector it is interesting to confront two indicators: services that occupy $70 \%$ of EU working population represent $20 \%$ share in total export and import within the Single Market. This disproportion can only partly be explained with lack of mobility of some service (some of them are territorially settled and require a coincidence of demand and supply happening at the same time in the same place). There are also types of services that can themselves, as a final good, cross the border without relocating the service provider or consumer (for example: guarantee service).

The effect of the above described disproportion, through the phenomenon of not sufficient competition mechanism, can be observed in the parameters describing efficiency of service sector. Productivity in European service sector is not growing and is distinctively lower than in other parts of the world - for instance in the USA. ${ }^{42}$

Implementing the Service Directive, and at the same time - in the time horizon of 2009 - 2010 - harmonization of state level law on free movement of services in the member countries, itself is a milestone of European integration. Just like Single Act or Maastricht Treaty, the Service Directive may deepen integration in a very important economy sector. It is enough to mention that services generate up to two thirds of EU GDP and engage up to 70\% of EU workforce population.

\footnotetext{
${ }^{42}$ R. Hlavaty, Liberalisation in Service - the Sooner, the Better, 11-12/2004/7.
} 
Following the logic of the service directive supporters, due to its positive impact on GDP growth, labour market and competitiveness of EU economy, it is necessary to point the coincidence of Lisbon Strategy target (2010) and the final incorporation the directives' content into states' legal systems (2010) seems more than symbolic. Additional coincidence that must be recognized is connected with transition periods on free movement of labour that were negotiated in Copenhagen in December 2002 (negotiations of Accession Treaty). In 2011 a mechanism that protects labor of such countries like France or Germany from the competition from CEE countries will expire. 2010 and 2011 appear to be the moments of truth for the so far social policy solutions and consequently for the total philosophy of the specific type of market economy and capitalism these countries perform.

Implementation of service directive, as well as the first years of its practical functioning will give answer to the question stated in this paper - if it will affect, following neofunctionalist logic of spillover mechanism, such spheres of social and economic life, like social and health policy - constituents to a welfare state.

This question, theoretically - in a speculative manner - is answered positively. Potentially, the changes the act will generate might be - in their scale and importance - comparable only to such milestones of integration like monetary union ${ }^{43}$. This can happen under the condition that neofunctionalists' theory of European integration will work and the "spill-over" mechanism will become an impulse and force integration in related, neighbouring sectors and dimensions ${ }^{44}$.

Consequently, theoretical legacy of neofunctionalism in this case seems to be under deductive argumentation - adequate and vital. Finding spillover mechanism in new areas positively verifies the potential of the old theory.

It is also important to observe that the free movement of products, capital and labour did not bring such a result, why free market of service would? What is in the specific characteristic of services (and its scale / share in the economy) that could be an effective impact on harmonization or unification of social policy? For example - the monetary union, that theoretically also is a pre-requisite for harmonizing other economic policies, did not function so. The member states do not decide to go any deeper than what was initially agreed in the form of Maastricht Treaty (convergence criteria).

${ }^{43}$ Services account for 70per cent of EU gross domestic product, but only 20 per cent of cross-border trade - unnecessary regulatory and administrative burdens.

${ }^{44}$ Functionalism assumes economic determinism: developing trade, creates pressure on tightening international co-operation, that should lead to political integration. Such a cooperation at a certain stage becomes institutionalised. 
Nevertheless, the budgetary criteria do act, to some extent, as spillover mechanism - not from one sector to another, but from one sphere (regulative) to another sphere (redistributive). Union does not have much competences in deciding on the structures of budget policy, it has however at its disposal the right to control the maximum budget deficit and public debt, which has purely regulatory nature, but effectively impacts states redistributive actions. ${ }^{45}$

Coming back to services and its pressure on social models, it is important to notice that such a potential development could be perceived as a one more step of the Communities towards federalism.

From this point of view, freeing the service market (from the protectionism domain of the state) may act as a pre-condition - according to neofunctionalists' theory - for deepening integration (for example, regulatory harmonization of contributions to the social protection system). Certainly, the bigger the disparities (expressed in GDP per capita PPS ${ }^{46}$ ) between the economies are, the more effectively the competition pressure of the new member states' citizens influences the socioeconomic systems of wealthier countries.

Paradoxically, the smaller the gap there is - and projecting the current trend of catching up dynamics, we can predict they will soon shrink - the weaker the pressure acts.

Consequently, lessening difference in labor costs, weakens the motivation (of the so called "old union") to reform expensive welfare systems, as they become less and less important determinants of the competitiveness (at least in internal dimension).

In the perspective of the presented argumentation, it seems that together with time process (most importantly, growing prosperity of new member states - and as a consequence: higher costs of labor, welfare system, etc.), the eventual deepening integration - in social policy area - is becoming less and less likely. In such a prism, the famous Bolkenstein's Directive loses its power and strength. Consequently the time seems to be an important determinant here. Currently, the spillover mechanism is more likely to generate pressure on harmonization in social policies dimension, rather than later - when the disparities among member states are going to be narrowed.

45 T.J. Borzel, Mind the gap! European integration between level and scope, "Journal of European Public Policy" 2005, No. 12.

${ }^{46}$ Gross domestic product per capita expressed in Purchasing Power Standard 